\title{
RATIONAL EMOTIVE BEHAVIOUR THERAPY (REBT) DALAM MENANGANI KECEMASAN PENDERITA EKSTRAPIRAMIDAL SINDROM MAHASISWA UIN SUNAN AMPEL SURABAYA
}

\author{
Nurul Faizah \\ Pascasarjana Universitas Islam Negeri Sunan Kalijaga, Yogyakarta 555181, Indonesia \\ nurul.faizahasbriy@gmail.com
}

; Received : ; Accepted :

; Published :

\begin{abstract}
The focus of this research is to find out how the process and results of Rational Emotive Behaviour Therapy (REBT) to deal with anxiety in patients Extrapyramidal Syndrome student of UIN Sunan Ampel Surabaya. The subjects in this research was a student of the Faculty of Da'wa and Communication UIN Sunan Ampel Surabaya 3rd semester who suffer from anxiety disorders because Extrapyramidal syndrome since the age of 10 years. This research uses qualitative research methods, with a case study and comparative descriptive analysis, the researchers compared before and after the counseling process using Rational Emotive Behaviour Therapy (REBT). The results of this research showed that the process of Rational Emotive Behaviour Therapy (REBT) in dealing with anxiety in patients Extrapyramidal syndrome using three techniques on REBT approaches (techniques disputing irrational belief, rational emotive imagery techniques, and modelling techniques) that do quite successful. It can be seen from the values obtained in the calculation by the standard test with a percentage of 50\% - 75\% which can be considered quite successful.
\end{abstract}

Keywords: Rational Emotive Behavior therapy, Anxiety

Sudah menjadi suatu keniscayaan, manusia diciptakan dengan segala kekurangan yang menandakan bahwa manusia hanyalah ciptaan yang tidak sempurna karena kesempurnaan hanya milik Allah SWT. Manusia memiliki kelebihan tersendiri diantara makhluk lainnya juga diantara manusia satu dan yang lainnya. Namun bukan hanya kelebihan, kekurangan juga ikut melengkapi dan menjadi suatu pembeda antara satu manusia dan yang lainnya. Mengutip salah satu firman Allah SWT dalam Qs. Sad 38: 27. 


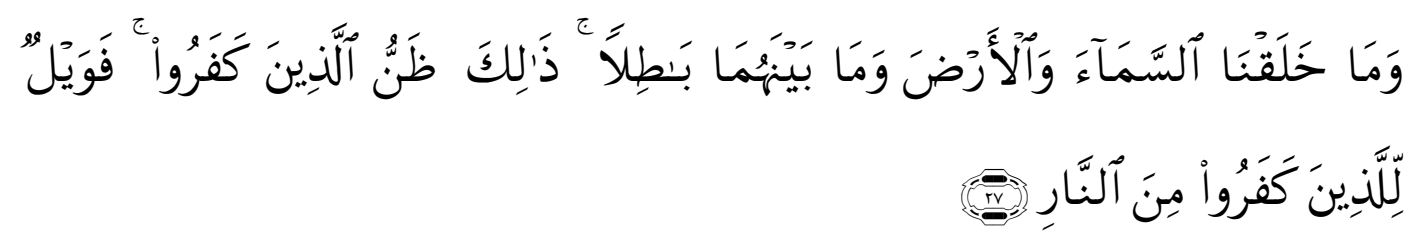

Artinya: Dan Kami tidak menciptakan langit dan bumi dan apa yang ada antara keduanya tanpa hikmah. yang demikian itu adalah anggapan orang-orang kafir, Maka celakalah orang-orang kafir itu karena mereka akan masuk neraka.

Setiap obat kemungkinan mempunyai efek samping, efek samping obat juga merupakan hasil interaksi antara molekul obat dengan sistem biologik tubuh. Efek samping obat tidak dapat dihilangkan sama sekali, tetapi dapat ditekankan dan dikurangi semininal mungkin dengan mengetahui kondisi yang mendorong terjadinya efek samping, sifat obat, serta cara pemakaian obat dan aturan dosis yang tepat. Diantaranya berupa gejala Ekstrapiramidal ini berupa parkinsonisme (hipokinesia, kekakuan anggota tubuh, dan tremor. Jadi tegantung reaksi dari pasien penderita penyakit tersebut.

Penelitian ini berawal dari fenomena kasus seorang anak mahasiswi yang sedang melanjutkan pendidikannya di Univesitas Islam Negeri Sunan Ampel Surabaya, saat kelas 4 SD terkena demam tinggi (Step) dan akhirnya konseli, muntah. Pada saat itu orang tua konseli merasa cemas dan panik, lalu orang tua konseli tersebut membawanya ke rumah sakit kemudian dokter memberi obat antimuntah. Obat tersebut ternyata menimbulkan efek samping yang berat berupa gangguan pada sistem saraf, tepatnya pada sistem Ekstrapiramidal pasien, yang menetap sampai sekarang. Gangguan tersebut biasa disebut Ekstrapiramidal.

Pada kasus ini peneliti menemukan fenomena kecemasan seseorang yang menderita Ekstrapiramidal Sindrom sejak umur 10 tahun, membuat ia merasa 
tidak berguna dan tidak memiliki kelebihan apapun, tidak bisa menerima dirinya dan takut tidak mampu membanggakan kedua orang tuanya. Berbagai pikiranpikiran irrasional yang disugestikan dalam pikirannya.

Salah satu diantara banyak gejala kesehatan yang membuat penderita merasa kekurangan adalah Ekstrapiramidal. Ekstrapiramidal Sindrom merupakan suatu gejala atau reaksi yang ditimbulkan oleh penggunaan jangka pendek atau jangka panjang dari pengobatan memakai antipsikotik golongan tipikal yang menyebabkan adanya gangguan keseimbangan antara transmisi asetilkolin dan dipamine pusat.

Hal ini berdampak pada kondisi psikis penderita penyakit tersebut, dengan beranggapan bahwa dengan penyakit tersebut penderita kurang mampu beradaptasi dengan lingkungannya dan merasa cemas, gugup bahkan merasa tertekan ketika berbicara di depan orang banyak sehingga pada penderita penyakit Ekstrapiramidal Sindrom ini cenderung tertutup dan minder.

Kecemasan yang berlebihan tidak dapat dikontrol pada penderita sehingga penyakitnya menjadi semakin terlihat dengan gerakan-gerakan yang tidak dapat dikendalikan pada dirinya, gerakan yang secara refleks terlihat ketika penderita merasa takut, gugup, cemas jika bertemu dengan orang-orang baru yang ia kenal dan bahkan ketika ia bercerita depan umum atau presentasi di depan kelas. Salah satu pendekatan yang dipandang tepat untuk menangani kecemasan pada penderita Ekstrapiramidal Sindrom adalah konseling Rational Emotive Behaviour Therapy. 
Rational Emotif Behaviour Therapy (REBT), mengajak individu memperbaiki dan mengubah sikap, cara berpikir, keyakinan serta pandangan individu yang irrasional menjadi rasional, sehingga individu tersebut mampu mengembangkan dirinya dan mencapai realiasasi diri yang lebih optimal. Pada Rational Emotif Behaviour Therapy (REBT) ini bertujuan untuk menghilangkan gangguan emosional yang dapat merusak diri individu seperti: Cemas, benci, takut, rasa bersalah dan marah yang mengakibatkan individu berpikir irrasional dan melatih individu agar mampu menghadapi kenyataan hidup secara rasional dan membangkitkan kepercayaan dirinya dan kemampuan diri individu.

Irrasional suatu yang tidak berdasarkan akal atau keputusan yang diambil cenderung tidak mampu dicerna oleh akal sehat, namun benar-benar terjadi dan dapat dirasakan dengan menggunakan pendekatan batin, dengan kata lain dalam hal ini logika tidak bicara, tapi batin dan perasaan saja.

Pada penilitian ini konseli berpikir dengan kondisi fisiknya ia tidak mampu menggapai apa yang diinginkannya, tidak mampu membahagiakan kedua orang tuanya, dan bahkan berpikiran ingin mati saja.

Konseli tidak percaya akan kemampuan pada dirinya karena dengan kekurangan fisiknya ia sering berpikiran irrasional. Pandangan dasar pendekatan ini tentang manusia adalah bahwa individu memiliki kecenderungan untuk berpikir irrasional yang salah satunya didapat melalui belajar sosial. Disamping itu individu juga memiliki kapasitas untuk belajar kembali berpikir rasional. Pendekatan ini bertujuan untuk mengajak individu mengubah pikiran-pikiran irrasionalnya menjadi pikiran yang rasional. 
Berdasarkan latar belakang permasalahan tentang tema tersebut di atas, maka peneliti memfokuskan rumusan permasalahannya yaitu bagaimana proses dan hasil Rational Emotive Behaviour Therapy (REBT) dalam menangani Kecemasan pada penderita Ekstrapiramidal Sindrom Mahasiswi Universitas Islam Negeri Sunan Ampel Surabaya.

Selanjutnya tujuan yang ingin dicapai pada penelitian ini adalah untuk mengetahui proses serta hasil Rational Emotive Behaviour Therapy (REBT) dalam menangani Kecemasan pada penderita Ekstrapiramidal Sindrom Mahasiswi Universitas Islam Negeri Sunan Ampel Surabaya.

\section{METODE}

Penelitian ini menggunakan pendekatan kualitatif. Penelitian kualitatif adalah penelitian yang menggunakan latar alamiah dengan maksud memahami fenomena tentang apa yang dialami oleh subjek penelitian secara holistik (utuh), dengan mendeskripsikan data dalam bentuk kata-kata dan bahasa, dan dengan memanfaatkan berbagai metode alamiah. Data dalam penelitian kualitatif yang dikumpulkan bukan berupa angka-angka melainkan data tersebut berasal dari naskah wawancara, cacatan lapangan, dokumen pribadi, cacatan memo, gambar dan dokumen resmi lainnya.

Sedangkan jenis penelitian yang digunakan adalah studi kasus (Case Study). Penelitian studi kasus, merupakan pendekatan dalam penelitian terfokus pada satu kasus yang dilakukan secara detail tentang kasus tersebut untuk mengembangkan deskripsi dan analisa mendalam tentang suatu kasus. Dalam studi kasus peneliti mengumpulkan informasi yang sangat detail bahkan yang 
bersifat pribadi pada individu dalam jangka waktu yang panjang guna untuk memahami perkembangan proses pada individu dalam penelitian studi kasus.

Subyek penelitian ini adalah seorang perempuan yang menderita Ekstrapiramidal Sindrom sejak kelas 4 SD, asal Bojogenoro dan saat ini sedang menempuh pendidikan S1 di Universitas Islam Negeri Sunan Ampel Surabaya program studi BKI semester 3. Adapun obyek penelitian dalam penelitian ini adalah kecemasan penderita Ekstrapiramidal Sindrom.

Teknik yang digunakan dalam penelitian ini adalah wawancara yaitu pengumpulan data dengan cara mengajukan pertanyaan secara lisan kepada informan, dan pertanyaan itu telah dipersiapkan dengan secara detail berserta instrumennya, atau percakapan dengan maksud tertentu, observasi partisipan yaitu pengamatan secara akurat terhadap fenomena-fenomena pada penelitian, dalam observasi partispan ini peneliti terlibat dengan keseharian orang yang sedang diamati. Dengan observasi ini, maka data yang diperoleh akan lebih lengkap sehingga mengetahui pada tingkat makna dari setiap perilaku yang nampak, dan dokumentasi yaitu metode pengumpulan data dengan cara mengumpulkan dokumen atau catatan peristiwa yang sudah berlalu, berupa tulisan atau karya monumental dari seseorang.

Data yang dihasilkan dari hasil pengumpulan sesuai teknik tersebut di atas selanjutnya dianalisa dengan manajemen data mentah atau yang belum terstruktur yang berasal dari data kuesioner kualitatif, wawancara kualitatif, observasi kualitatif data sekunder, refleksi tertulis, dan catatan lapangan yang terstruktur menjadi suatu kesatuan hasil penelitian. Analisa data dalam penelitian kualitatif 
berarti melakukan organisasi secara jelas dan rinci, komprehensif data-data menjadi kesimpulan ringkas untuk menghasilkan teori induktif yang berdasarkan pada data.

Hasil dari data yang diperoleh disajikan dalam bentuk "Deskriptif Komparatif" yaitu membandingkan hasil data dalam proses konseling yang dilakukan di lapangan dengan teori yang ada pada umumnya dan untuk membandingkan kondisi konseli antara sebelum dan sesudah pelaksanaan proses konseling, serta mengetahui berhasil tidaknya Rational Emotive Behaviour Therapy (REBT) dalam menangani kecemasan pada penderita Ekstrapiramidal

\section{Sindrom.}

\section{HASIL}

Seperti yang sudah konselor terangkan pada langkah evaluasi, konselor dapat mengetahui bahwa kecemasan yang dirasakan konseli cukup mengalami pengurangan pasca proses konseling dengan menanyakan secara langsung kepada konseli dan dengan memperhatikan serta mengamati secara non verbal perubahan yang ada pada diri konseli termasuk melakukan wawancara kepada teman sekelas dan sepesantrennya mengenai perubahan konseli.

Perubahan yang terjadi dalam diri konseli yaitu lebih semangat dalam menjalani kesehariannya ditandai dengan raut muka dan senyum yang terlihat, konseli juga menyatakan mulai bisa mengontrol ketakutannya dalam kelas, ketika bertemu orang baru, serta bisa mengurangi rasa gugup dan cemas yang dirasakannya terutama ketika berbicara di depan umum, orang lain, maupun orang yang dikenalnya meskipun masih terdapat sedikit rasa malu yang nampak. Pada 
tabel di bawah ini, disajikan kondisi konseli sebelum dan pasca proses konseling dengan Rational Emotive Behaviour Therapy (REBT), sebagai berikut:

Tabel 1. Kondisi konseli Sebelum Pelaksanaan Konseling

\begin{tabular}{|c|c|c|c|c|c|c|}
\hline \multirow{2}{*}{ No } & \multirow{2}{*}{ Pertanyaan } & \multicolumn{2}{|c|}{ Sebelum } & \multicolumn{3}{|c|}{ Sesudah } \\
\hline & & S $\quad$ KK & TP & $\mathbf{S}$ & KK & TP \\
\hline 1. & $\begin{array}{l}\text { Jatung berdetak cepat ketika saya berbicara } \\
\text { di depan umum }\end{array}$ & $\checkmark$ & & & & $\checkmark$ \\
\hline 2. & $\begin{array}{l}\text { Saya tidak tau apa yang saya ingin bicarakan } \\
\text { ketika berada di depan umum }\end{array}$ & $\checkmark$ & & & & $\checkmark$ \\
\hline 3. & $\begin{array}{l}\text { Saya merasa ketakutan jika disuruh dosen } \\
\text { menjelaskan di depan kelas }\end{array}$ & $\checkmark$ & & & & $\checkmark$ \\
\hline 4. & $\begin{array}{l}\text { Saya merasa kebingungan jika presentasi } \\
\text { atau berbicara depan umum }\end{array}$ & $\checkmark$ & & & & $\checkmark$ \\
\hline 5. & $\begin{array}{l}\text { Saya merasa tidak tenang jika sudah berada } \\
\text { di depan orang banyak }\end{array}$ & $\checkmark$ & & & $\checkmark$ & \\
\hline 6. & $\begin{array}{l}\text { Saya merasa gelisah ketika ada orang yang } \\
\text { melihat saya }\end{array}$ & $\checkmark$ & & & $\checkmark$ & \\
\hline 7 & $\begin{array}{l}\text { Saya merasa gemetaran jika berdiri di depan } \\
\text { orang banyak }\end{array}$ & $\checkmark$ & & & $\checkmark$ & \\
\hline 8 & $\begin{array}{l}\text { Saya merasa sedih jika saya tidak bisa } \\
\text { berbicara di depan umum. }\end{array}$ & $\checkmark$ & & $\checkmark$ & & \\
\hline 9 & $\begin{array}{l}\text { Saya merasa khawatir tidak bisa } \\
\text { membahagiakan orangtua }\end{array}$ & $\checkmark$ & & & & $\checkmark$ \\
\hline 10 & $\begin{array}{l}\text { Saya merasa malu ketika disuruh berbicara } \\
\text { didepan umum. }\end{array}$ & $\checkmark$ & & & $\checkmark$ & \\
\hline
\end{tabular}

Merujuk kepada hasil skala kecemasan yang telah dijawab oleh konseli pasca konseling seperti yang tertulis diatas, sebagian besar pilihan konseli berubah menjadi lebih baik, dengan demikian dapat disimpulkan bahwa konseli mengalami perubahan yaitu menurunnya tingkat kecemasan yang dirasakan konseli, sebelum dilaksanakan sesi konseling, konseli merasakan kecemasan yang tinggi, namun setelah melaksanakan sesi konseling, kecemasan yang disarakan konseli menurun cukup signifikan pada tingkat kecemasan sedang.

Selanjutnya, untuk melihat tingkat keberhasilan dan kegagalan konseling yang telah dilakukan, serta peniliaian akhir terhadap hasil skala kecemasan diatas, 
peneliti akan melakukan uji coba dengan berpedoman pada prosentase perubahan perilaku dengan standart uji coba sebagai berikut:

$>75 \%$ atau $75 \%$ sampai dengan $100 \%$ dikategorikan berhasil.

$50 \%$ sampai dengaaan $75 \%$ dikategorikan cukup berhasil.

$<50 \%$ dikategorikan kurang berhasil.

Ada 10 pertanyaan tentang gejala kecemasan pada penderita Ekstrapiramidal Sindrom mahasiswi Universitas Islam Negeri Sunan Ampel Surabaya seperti yang tertulis pada tabel di atas. Selanjutnya, hasil dari skala kecemasan di atas akan dihitung guna mencari tahu tingkat keberhasilan proses konseling yang telah dilakukan, sebagai berikut:

Gejala yang sudah tidak dilakukan $=5$ point $\rightarrow 5: 10 \times 100 \%=50 \%$

Gejala yang terkadang masih dilakukan $=4$ point $\rightarrow 4: 10 \times 100 \%=40 \%$

Gejala yang sering dilakukan $=1$ point $\rightarrow 1: 10 \times 100 \%=10 \%$

Berdasarkan prosentase dari hasil penghitungan di atas, dapat diketahui bahwa proses Rational Emotive Behaviour Therapy (REBT) dalam menangani kecemasan pada penderita Ekstrapiramidal Sindrom mahasiswi di Universitas Islam Negeri Sunan Ampel Surabaya, dikategorikan cukup berhasil. Hal ini didapat dari hasil penghitungan dengan standar uji coba yang mendapat prosentase $50 \%$ karena termasuk ke dalam standar uji 50\% sampai dengan $75 \%$ yang dikategorikan cukup berhasil.

Dengan demikian, dapat disimpulkan bahwa proses Rational Emotive Behaviour Therapy (REBT) dalam menangani kecemasan pada penderita 
Ekstrapiramidal Sindrom mahasiswi Universitas Islam Negeri Sunan Ampel Surabaya dinyatakan cukup berhasil.

\section{PEMBAHASAN}

Sebagaimana yang telah dipaparkan di atas, berdasarkan prosentase dari hasil penghitungan pada tahap analisis, dapat diketahui bahwa proses Rational Emotive Behaviour Therapy (REBT) dalam menangani kecemasan pada penderita Ekstrapiramidal Sindrom mahasiswi di Universitas Islam Negeri Sunan Ampel Surabaya, dikategorikan cukup berhasil. Hal ini didapat dari hasil penghitungan dengan standar uji coba yang mendapat prosentase 50\% karena termasuk ke dalam standar uji 50\% sampai dengan $75 \%$ yang dikategorikan cukup berhasil.

Dengan demikian meskipun sedikit, konseli mengalami penurunan efek Ekstrapiramidal Sindrom terutama pada kecemasan yang dirasakannya. Sebelumnya kecemasan konseli tidak dapat dikontrol dan berlebihan sehingga penyakitnya menjadi semakin terlihat dengan gerakan-gerakan yang tidak dapat dikendalikan pada dirinya, gerakan yang secara refleks terlihat ketika penderita merasa takut, gugup, cemas jika bertemu dengan orang-orang baru yang ia kenal dan bahkan ketika ia bercerita depan umum atau presentasi di depan kelas.

Dengan melakukan konseling menggunakan Rational Emotive Behaviour Therapy yang terdiri dari beberapa langkah (a) engane with client yaitu bekerja sama dengan konseli, (b) assess the problem, person, and situation yaitu melakukan assessmen terhadap masalah, diri konseli dan situasi, (c) prepare the client for therapy yaitu mempersiapkan konseli untuk terapi, (d) implement the treatment program yaitu mengimplementasikan program treatmen, (e) evaluate 
progress yaitu mengevaluasi kemajuan, dan (f) repare the client for termination yaitu mempersiapkan konseli untuk mengakhiri konseling, konseli dapat memperbaiki dan mengubah sikap, cara berpikir, keyakinan serta pandangannya yang irrasional menjadi rasional, dan konseli mampu mengembangkan dirinya dan mencapai realiasasi diri yang lebih optimal dari sebelumnya.

\section{KESIMPULAN}

Berdasarkan data yang diperoleh beserta hasil penelitian yang dilakukan terkait Rational Emotive Behaviour Therapy (REBT) dalam menangani Kecemsan pada Penderita Ekstrapiramidal Sindrom Mahasiswi Universitas Islam Negeri Sunan Ampel Surabaya, maka kesimpulan yang dapat diambil yaitu, pertama proses Rational Emotive Behaviour Therapy (REBT) dalam menangani kecemasan pada penderita Ekstrapiramidal Sindrom, dilakukan secara bertahap sebagaimana tahapan konseling pada umumnya, yaitu identifikasi masalah, diagnosis, prognosis, treatment / terapi dan diakhiri dengan follow up / evaluasi. Proses konseling dilakukan menggunakan langkah serta teknik-teknik dalam pendekatan Rational Emotive Behaviour Therapy (REBT). Adapun langkahlangkah Rational Emotive Behaviour Therapy (REBT) adalah (1) engane with client yaitu bekerja sama dengan konseli, (2) assess the problem, person, and situation yaitu melakukan assessmen terhadap masalah, diri konseli dan situasi, (3) prepare the client for therapy yaitu mempersiapkan konseli untuk terapi, (4) implement the treatment program yaitu mengimplementasikan program treatmen (dengan menggunakan teknik teknik disputing irrational beliefs, teknik rational emotive imagery, dan terakhir modelling), (5) evaluate progress yaitu 
mengevaluasi kemajuan, (6) prepare the client for termination yaitu mempersiapkan konseli untuk mengakhiri konseling.

Kedua hasil dari proses Rational Emotive Behaviour Therapy (REBT) dalam menangani kecemasan pada penderita Ekstrapiramidal Sindrom menunjukan proses konseling yang dilakukan konselor cukup berhasil dalam menangani kecemasan yang dirasakan oleh konseli. Hal ini dapat dilihat dari wawancara terhadap konseli pasca konseling, observasi mengenai keseharian konseli pasca konseling, serta nilai yang didapat dari hasil penghitungan dengan standar uji coba dengan prosentase 50\%, karena termasuk ke dalam standar uji $50 \%$ sampai dengan $75 \%$ yang dikategorikan cukup berhasil, maka hasil dari proses konseling dengan Rational Emotive Behaviour Therapy (REBT) dalam menangani kecemasan pada penderita Ekstrapiramidal Sindrom dikatakan cukup berhasil.

Selanjutnya peneliti memberikan saran kepada Mahasiswa BKI maupun peneliti selanjutnya yaitu dikarenakan penelitian ini berfokus pada proses Rational Emotive Behaviour Therapy (REBT) yang diaplikasikan dalam menangani kecemasan pada penderita Ekstrapiramidal Sindrom dengan melihat proses dan hasilnya, maka penulis menyarankan adanya penelitian lanjutan tentang pendekatan Rational Emotive Behaviour Therapy (REBT), penderita Ekstrapiramidal Sindrom, serta tentang gangguan kecemasan maupun gangguan emosi lainnya. Hal ini sangat perlu guna mengembangkan khazanah ilmu pengetahuan mahasiswa BKI serta peneliti selanjutnya, mengembangkan serta 
menyempurnakan penelitian ini yang jauh dari sempurna karena masih banyak kekurangan, dan dapat mempersembahan karya terbaik.

\section{DAFTAR PUSTAKA}

Ahli, Pengertian Menurut Para. (15 januari 2017) Arti kata \& Definisi menurut para ahli "Rasional dan Irrasional" www.pengertianmenurutparaahli.net/pengertianrasional-irrasional/.com.

Ali, M. (1987). Penelitian Kependidikan Prosedur dan Strategi. Bandung: Angkasa.

Corey, Gerald. (2005). Teori dan Praktek Konseling \& Psikoterapi. Bandung: PT Refika Aditama.

Creswell, John W. (2015). Penelitian Kualitatif \& Desain Riset, Yogyakarta: Pustaka Pelajar.

Davidoff, Linda L. (1998). Psikologi Suatu pengantar. Jakarta: Erlangga.

Hanurawan, Fattah. (2016). Metode Penelitian Kualitatif untuk Ilmu Psikologi. Jakarta: PT. Raja Grafindo Persada.

Komalasari, Gatina. dkk. (2011). Teori dan Tekinik Konseling. Jakarta: Permata Putri Media.

Latipun. (2003). Psikologi Konseling. Malang: UMM Press.

Moleong, Lexy J. (2005). Metodelogi Penelitian kualitatif. Bandung:PT Remaja Kosdakarya.

RI, Kementrian Agama. (2012). Al-Qur'an dan Terjemahan. Bandung: Penerbit Wali.

Sugiyono. (2015). Metode Penelitian Pendidikan (Pendekatan Kuantitatif, kualitatif dan $R \& D)$. Bandung: Penerbit Alfabeta.

Susilowati, Sri, (2005). "Penyelidikan Efek samping Haloperidol dan Chlorpromazine: Studi kasus pada pasien Rawat inap Rumah Sakit Jiwa Daerah Dr. Amino Gongohutomo Semarang". Fakultas Farmasi Universitas Wahid Hasyim Semarang. 